\title{
The Germination of Spores of Clostridium tetani
}

\author{
By J. G. SHOESMITH AND K. T. HOLLAND \\ Department of Bacteriology, School of Medicine, University of Leeds, \\ Leeds, LS2 $9 N L$
}

(Accepted for publication 2 November 1971)

SUMMARY

The spores of Clostridium tetani will germinate aerobically and anaerobically in complex media such as heart infusion broth or tryptone with yeast extract at $37^{\circ}$ and $\mathrm{pH} 7 \cdot 5$. A synthetic medium as effective as heart infusion broth for germination under both aerobic and anaerobic conditions consists of I mM-methionine, I00 mM-lactate, $82 \mu \mathrm{M}$-nicotinamide, $280 \mathrm{mM}^{-\mathrm{Na}^{+}}$in $40 \mathrm{~mm}$-phosphate buffer, $\mathrm{pH}$ 7.5. Anaerobic germination would take place in either methionine with $\mathrm{Na}^{+}$or lactate and nicotinamide with $\mathrm{Na}^{+}$, but all the germinants were essential aerobically. Heat activation did not occur and thioglycollate increased the rate of germination.

\section{INTRODUCTION}

Most of the work on the germination of the bacterial spore has been directed towards the aerobic sporing bacilli (see Gould \& Hurst, 1969). With clostridia the germination requirements are often complex (Hitzman, Halvorson \& Ukita, I957; Gibbs, I964, I967; Fujioka \& Frank, 1966; Bergère, 1969; Holland, Barker \& Wolf, I970; Rowley \& Feeherry, 1970; Barker, Gould \& Wolf, 197I).

The present study was undertaken to examine the early stages of development from the spores of Clostridium tetani with the object of finding an explanation for the unexpected toxicity of heat- and radiation-damaged spores of this organism (Shoesmith, 1964). Fildes and his colleagues established the oxidation-reduction potential necessary for the germination and outgrowth of C. tetani (Knight \& Fildes, 1930) and Kaufman \& Humphries (1958) described a synthetic medium suitable for the vegetative growth but the necessary nutritional factors for germination were not known. Our preliminary tests showed that simple meat infusions and tryptic or peptic digests had a poor capacity to stimulate germination, even though they would support vegetative growth. In media of a more complex nature, such as heart infusion broth (Difco), most of the spores germinated within I h (J. G. Shoesmith, unpublished observations). These results provided a basis for the determination of the substances stimulatory for germination in C. tetani and a preliminary report has already been made (Shoesmith \& Holland, 1968).

\section{METHODS}

Organism. Clostridium tetani CN 76I (Wellcome Research Laboratories Culture Collection) was used throughout the work and was maintained in cooked meat medium (Southern Group Laboratory, Hither Green Hospital, London, S.E. 13).

Production and harvesting of spores. Cooked meat medium, $(80 \mathrm{ml})$, after centrifuging at $2500 \mathrm{~g}$ for $30 \mathrm{~min}$ to remove meat particles, was held in polypropylene centrifuge tubes (MSE, Crawley, Sussex) and inoculated with $\mathrm{I} \mathrm{ml}$ of an $\mathrm{I} 8 \mathrm{~h}$ culture of the organism and incubated at $37^{\circ}$ in an anaerobic jar. After 5 days, 60 to $70 \%$ of the organisms in the culture 
were phase-bright spores and about $8 \%$ were phase-dark spores. The organisms were washed in distilled water by centrifuging, the first three times at $2500 \mathrm{~g}$ for $30 \mathrm{~min}$ and then repeatedly at $430 \mathrm{~g}$ for $30 \mathrm{~min}$ until over $90 \%$ of the organisms were phase-bright spores and no vegetative cells were present. All centrifugings were carried out at $5^{\circ}$ to minimize spore germination and the pellets were dispersed with sterile glass beads $(4.5$ to $5.5 \mathrm{~mm}$ diam.). The final spore suspensions were stored at $4^{\circ}$. These spores were always contained in their sporangia. Since the sporangia could not be removed without enzyme treatment most experiments were carried out with the sporangia present.

Media and chemicals. The following media were prepared in stock aqueous solutions at a sufficiently high concentration to allow dilution and addition of other components to give appropriate final concentrations; they were sterilized by autoclaving at $15 \mathrm{lb} / \mathrm{in}^{2}$ for I 5 min: heart infusion broth (Difco), Io \% (w/v); Tryptone $\mathrm{T}$ (Oxoid), $20 \%$ (w/v); yeast extract (Difco), $8 \%$ (w/v).

Amino acids, purines, pyrimidines, vitamins and coenzymes were prepared in stock aqueous solutions at $200 \mathrm{mM}$ in most cases and stored frozen at $-20^{\circ}$ ready for dilution to the required final concentration. Thioglycollic acid and ascorbic acid were prepared at $200 \mathrm{~mm}$ at pH 6.8 , stored at $4^{\circ}$, and diluted to a final concentration of $\mathrm{Io} \mathrm{mM}$. NaCl (spectroscopic grade) $2 \mathrm{M}$ and $\mathrm{NaH}_{2} \mathrm{PO}_{4}-\mathrm{Na}_{2} \mathrm{HPO}_{4}$ buffer, $200 \mathrm{mM}, \mathrm{pH} 7 \cdot 5$, were stored at $4^{\circ}$ and the latter used at $40 \mathrm{~mm}$.

Measurement of germination. Germination was most conveniently determined by phasecontrast microscopy of slide-culture preparations. Mixtures of compounds to be tested were prepared from stocks in suitable proportions and the $\mathrm{pH}$ adjusted with $\mathrm{M}-\mathrm{HCl}$ or $\mathrm{M}-\mathrm{NaOH}$, the volume made up to $5.5 \mathrm{ml}$ and kept at $-20^{\circ}$ until needed.jThe desired $\mathrm{Na}^{+}$concentration was obtained by addition of $\mathrm{NaCl}$. Before testing, the media were thawed and $0.55 \mathrm{ml}$ was added to $100 \times 12 \mathrm{~mm}$ tubes at $50^{\circ}$ containing $0.05 \mathrm{ml}$ sodium thioglycollate, $200 \mathrm{~mm}$, $\mathrm{pH} 6.8$ to maintain anaerobic conditions and $0.4 \mathrm{ml} 2 \%$ Oxoid no. 2 agar, $\mathrm{pH} 7.5$, previously melted and brought to $50^{\circ}$. For aerobic conditions water replaced the thioglycollate. A loopful of spore suspension in distilled water was allowed to dry on a no. $1 \frac{1}{2}$ coverglass at room temperature and inverted over three drops of the medium sufficient to fill the well of a $I \times 3$ in hollow-ground slide warmed to $50^{\circ}$. The slides were incubated at $37^{\circ}$ in a covered tray $(6.5 \times 7 \times 2.5 \mathrm{in})$ immersed almost to the lid in a water bath. The slides were removed at intervals to obtain counts of phase-bright spores and of the total number of spores using a Beck (Ealing-Beck Ltd, Greycaine Road, Watford, WD2 $4 \mathrm{PW}$ ) binocular phase-contrast microscope fitted with a mechanical stage. The spores were examined by means of a $2 \mathrm{~mm}$ oil-immersion phase-contrast objective and $\times$ IO eye-pieces with greenfiltered illumination from a high-intensity lamp. A graticule in one eye-piece facilitated counting and the numbers of phase-bright and total spores were recorded on tally-counters. The counting of 100 spores thus gave a direct count of the percentage of phase-bright spores.

In a few preliminary experiments the effect of germinants was determined from the extinction at $600 \mathrm{~nm}$. To do this it was necessary to obtain spores free from their sporangia and this was accomplished by treatment with an enzyme system produced by a mould (J. G. Shoesmith, unpublished observations).

Unless otherwise stated all germination tests were carried out in the presence of Io mMsodium thioglycollate to maintain anaerobic conditions. Heart infusion broth $(2.5 \%, \mathrm{w} / \mathrm{v})$ and ro mM-thioglycollate were used as positive and negative controls. 
Table 1. The effect of heating on the subsequent germination of spores in $2.5 \%$ heart infusion broth anaerobically at $37^{\circ}, \mathrm{pH} 7.5$

$\begin{array}{ccc}\begin{array}{c}\text { Heating for } \\ \text { Io min at }\end{array} & \begin{array}{c}\text { Time for 50\% } \\ \text { germination } \\ (\mathrm{min})\end{array} & \begin{array}{c}\text { Viable } \\ \text { count } \\ \left(\times 10^{-6}\right)\end{array} \\ 4^{\circ} & 2 \mathrm{I} & - \\ 70^{\circ} & 2 \mathrm{I} & 40 \\ 75^{\circ} & 2 \mathrm{I} & 43 \\ 80^{\circ} & 2 \mathrm{I} & 45 \\ 85^{\circ} & 24 & 35 \\ 90^{\circ} & 32 & 33 \\ 95^{\circ} & 54 & 34 \\ 100^{\circ} & 420 & 5.0\end{array}$

Table 2. Anaerobic germination in complex media

\begin{tabular}{|c|c|}
\hline $\begin{array}{l}\text { Pha } \\
\text { after }\end{array}$ & $\begin{array}{l}\text { e-bright spores } \\
\text { hat } 37^{\circ} \mathrm{pH} 7.5 \\
(\%)\end{array}$ \\
\hline $2.5 \%$ heart infusion broth (HIB) & 4 \\
\hline $2.5 \%$ HIB diffusible fraction $*$ & 5 \\
\hline $2 \cdot 5 \%$ HIB non-diffusible fraction* & 85 \\
\hline $\begin{array}{l}2.5 \% \text { HIB non-diffusible and diffusible } \\
\text { fractions recombined }\end{array}$ & 5 \\
\hline $5.0 \%$ Tryptone $\mathrm{T}$ & 52 \\
\hline $2 \cdot 5 \%$ Tryptone $\mathrm{T}$ & 66 \\
\hline $2.0 \%$ yeast extract & 86 \\
\hline $\mathrm{I} \cdot 0 \%$ yeast extract & 83 \\
\hline $5 \%$ Tryptone $T+1 \%$ yeast extract & 30 \\
\hline $5 \%$ Tryptone $\mathrm{T}+\mathrm{I} \%$ yeast extract $+\mathrm{I} 0 \mathrm{mM}-\mathrm{NaHCO}_{3}$ & 14 \\
\hline Control, no germinants & 9i \\
\hline
\end{tabular}

* Heart infusion broth was dialysed against distilled water at $4^{\circ}$ and the diffusible and non-diffusible fractions freeze-dried and redissolved in water to the original volume.

\section{RESULTS}

The effect of heating on spore germination

There was no change in the viable count and rate of germination of the spores of Clostridium tetani after heating at temperatures in the range $70^{\circ}$ to $85^{\circ}$ (Table I). Complete germination occurred in both heated and unheated spores. Heating at higher temperatures decreased the rate of germination. There was therefore no evidence of heat-activation with these spores and they were not heated in the following experiments concerned with the determination of the germinants.

\section{Determination of germinants}

Preliminary experiments using changes in extinction to detect germination showed that $2.5 \%(\mathrm{w} / \mathrm{v})$ heart infusion broth could be replaced by $2.5 \%(\mathrm{w} / \mathrm{v})$ Tryptone $\mathrm{T}$ combined with $\mathrm{I} \cdot 0 \%(\mathrm{w} / \mathrm{v})$ yeast extract. This method required the spores to be freed from their sporangia, and also changes in extinction did not always correspond to changes in phasecontrast appearance, ability to take up simple stains and heat resistance. Estimation of the proportion of phase-bright spores was therefore used to measure germination in all other experiments and results obtained by this method showed that the necessary factors for 
Table 3. Effect of vitamins on anaerobic germination of spores

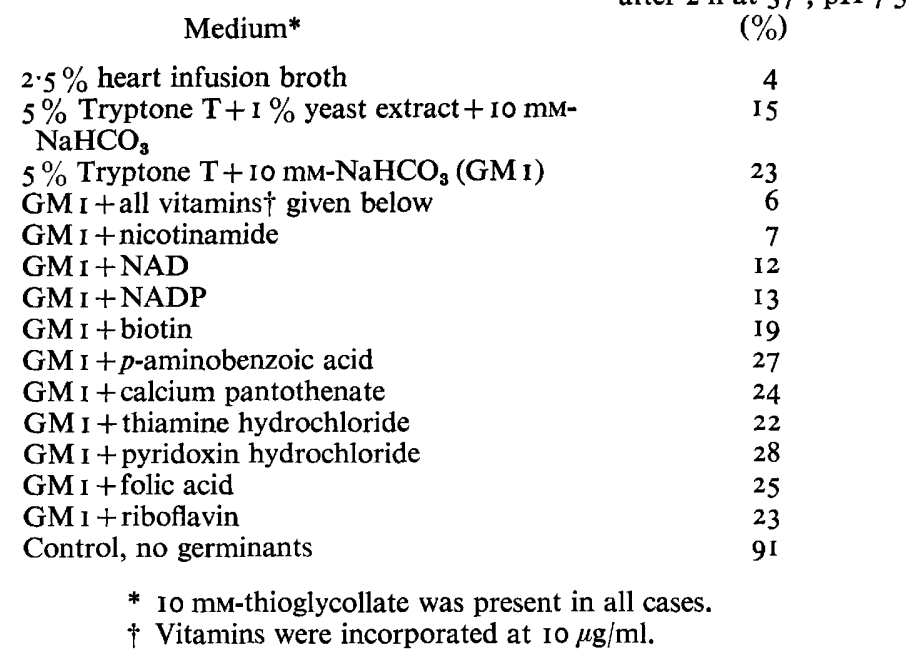

Phase-bright spores after 2 h at $37^{\circ}, \mathrm{pH} 7.5$

$2 \cdot 5 \%$ heart infusion broth

$5 \%$ Tryptone $\mathrm{T}+\mathrm{I} \%$ yeast extract + $10 \mathrm{~mm}-$

$5 \%$ Tryptone $\mathrm{T}+\mathrm{I} 0 \mathrm{~mm}-\mathrm{NaHCO}_{3}(\mathrm{GM} \mathrm{I})$

GM I + all vitamins $\nmid$ given below

GM I + nicotinamide

GM I + NAD

GM I + biotin

$\mathrm{I}+p$-aminobenzoic

GM I + pyridoxin hydrochloride

GM + riboflavin

$\dagger$ Vitamins were incorporated at $10 \mu \mathrm{g} / \mathrm{ml}$.

Table 4. Effect of carboxylic acids on the anaerobic germination of spores in the presence of amino acids

\section{Medium}

$2 \cdot 5 \%$ heart infusion broth

GM 2*

GM 2 + all acids given below

GM 2 + lactate

GM 2 + pyruvate

GM 2 + oxaloacetate

GM 2 + malate

GM 2 + fumarate

GM2 + succinate

Control, no germinants
Phase-bright spores after $2 \mathrm{~h}$ at $37^{\circ}(\%)$

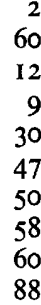

60

12

30

47

88

* GM 2 consists of 23 amino acids each at I mM (listed in Table 5), phosphate buffer ( $40 \mathrm{~mm}, \mathrm{pH} 7 \cdot 5$ ), $\mathrm{NaCl}(50 \mathrm{mM}), \mathrm{NaHCO}_{3}$ (IO mM), nicotinamide ( $\left.82 \mu \mathrm{M}\right)$.

germination were water-soluble, dialysable and could be provided with a mixture of yeast extract, Tryptone $\mathrm{T}$ and $\mathrm{NaHCO}_{3}$ (Table 2).

A mixture of ten vitamins, each at $10 \mu \mathrm{g} / \mathrm{ml}$, was an adequate substitute for yeast extract in this complex medium, with nicotinamide being the simplest and most effective single vitamin (Table 3). Nicotinamide therefore replaced yeast extract in further tests which showed that a mixture of amino acids and carboxylic acids with $40 \mathrm{~mm}$-phosphate buffer and $50 \mathrm{~mm}-\mathrm{NaCl}$ could replace Tryptone $\mathrm{T}$. (The salt concentrations were chosen to simulate those in Tryptone T (Oxoid Manual, 1965).) Lactate was the most effective carboxylic acid though pyruvate had some activity (Table 4), and of the amino acids, methionine, phenylalanine and leucine were the most effective, with isoleucine being less so and alanine being somewhat inhibitory (Table 5). Germination could therefore take place anaerobically at a rate similar to that in $2.5 \%(\mathrm{w} / \mathrm{v})$ heart infusion broth in a defined medium consisting of 
Table 5 Effect of amino acids on anaerobic spore germination

Medium

$2.5 \%$ heart infusion broth

GM 3*

GM 3 + amino acids of group A

$\mathrm{GM}_{3}+$ amino acids of group $B$

$\mathrm{GM}_{3}+$ amino acids of group $\mathrm{C}$

GM $_{3}+$ amino acids of groups $A$ and $B$

GM $_{3}+$ amino acids of groups $A$ and $C$

$\mathrm{GM}_{3}+$ amino acids of groups $B$ and $C$

$\mathrm{GM}_{3}+$ amino acids of groups $\mathrm{A}, \mathrm{B}$ and $\mathrm{C}$

Group A

$\mathrm{GM}_{3}+$ alanine

GM 3 + arginine

GM 3 + asparagine

GM 3 + aspartic acid

GM 3 + glutamic acid

$\mathrm{GM}_{3}+$ phenylalanine

GM 3 + leucine

GM $_{3}+$ creatinine

Group B

GM 3 + creatine

$\mathrm{GM}_{3}$ + cystine

$\mathrm{GM}_{3}$ + diaminopimelic acid

$\mathrm{GM}_{3}+$ glycine

$\mathrm{GM}_{3}$ + histidine

GM 3 + hydroxyproline

GM 3 + isoleucine

$\mathrm{GM}_{3}+$ lysine

GM 3 + methionine

Group C

GM 3 + proline

$\mathrm{GM}_{3}$ + serine

GM 3 + threonine

GM 3 + tryptophan

GM 3 + tyrosine

$\mathrm{GM}_{3}+$ valine

$\mathrm{GM}_{3}$ + methionine + phenylalanine + leucine

$\mathrm{GM}_{3}+$ amino acids of groups $\mathrm{A}, \mathrm{B}$ and $\mathrm{C}$ except methionine, phenylalanine and leucine
Phase-bright spores after $2 \mathrm{~h}$ at $37^{\circ}$

$(\%)$

4
67

19

48

I 4

17

20

17

9

87

58

69

63

68

29

I 5

66

60

69

67

68

$6 \mathrm{r}$

69

40

80

20

62

6 I

65

57

60

$7 \mathrm{I}$

6

50

* $\mathrm{GM}_{3}$ consists of phosphate buffer ( $\left.40 \mathrm{~mm}, \mathrm{pH} 7.5\right), \mathrm{NaCl}$ (50 mM), $\mathrm{NaHCO}_{3}$ (10 mM), lactate (I mM) and nicotinamide $(82 \mu \mathrm{M})$.

leucine, methionine, phenylalanine, and lactate each at I $\mathrm{mM}$, nicotinamide $(82 \mu \mathrm{M})$, $\mathrm{NaHCO}_{3}$ ( $10 \mathrm{mM}$ ), $\mathrm{NaCl}(50 \mathrm{~mm})$ and sodium phosphate buffer $(40 \mathrm{mM}, \mathrm{pH} 7 \cdot 5)$.

Testing different combinations of the various constituents showed that methionine, lactate, nicotinamide and phosphate buffer were effective, though leucine, phenylalanine, lactate, nicotinamide, $\mathrm{NaHCO}_{3}$ and $\mathrm{NaCl}$ had about the same activity (Table 6). Since the former system was simpler it was chosen for more detailed examination.

Increasing the lactate concentration to $100 \mathrm{mM}$ and total $\mathrm{Na}^{+}$to $280 \mathrm{mM}$ with I mMmethionine and $82 \mu \mathrm{M}$-nicotinamide gave a medium capable of germinating the spores as rapidly as $2.5 \%$ (w/v) heart infusion broth, both aerobically and anaerobically (Fig. I). Each germinant in this medium was then omitted or varied by tenfold changes in concentra- 


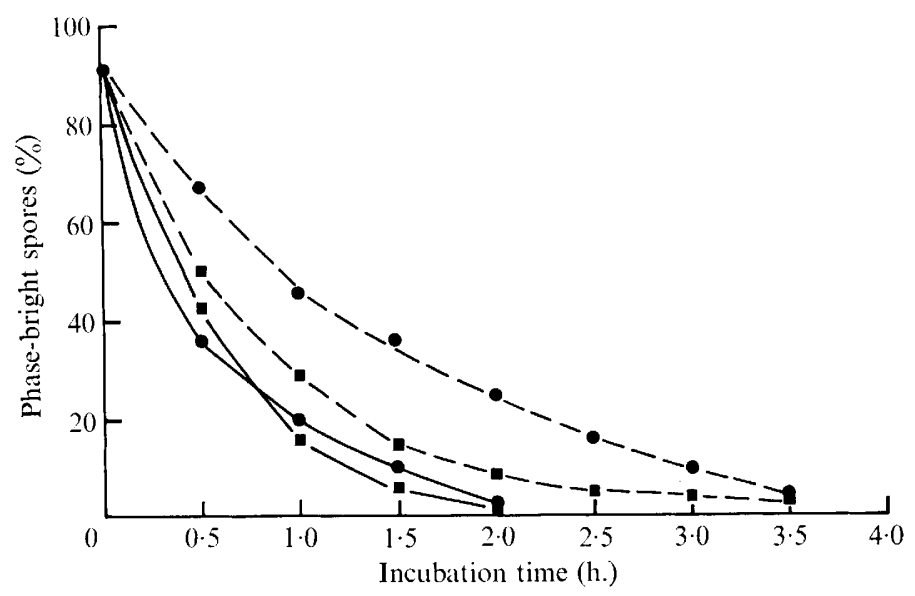

Fig. I. Germination of spores of Clostridium tetani in $2.5 \%(\mathrm{w} / \mathrm{v})$ heart infusion broth $(0)$ and in methionine (I mM), nicotinamide $(82 \mu \mathrm{M})$, lactate (100 mM) and $\mathrm{Na}^{+}(280 \mathrm{mM})(\square)$ at $37^{\circ}, \mathrm{pH} 7 \cdot 5$. Germination under aerobic conditions is shown by the broken line, under anaerobic conditions by the solid line.

Table 6. Anaerobic germination of spores in various synthetic media supplemented with amino acids at $37^{\circ}, \mathrm{pH} 7 \cdot 5$

Compounds for basal medium

$\mathrm{NaHCO}_{3}$ (10 mM)

$\mathrm{NaCl}$ (50 mM)

Phosphate buffer (40 $\mathrm{mm}$ )

Nicotinamide $(82 \mu \mathrm{M})$

Lactate (I mM)
Compounds present in basal medium

\begin{tabular}{|c|c|c|c|c|c|c|}
\hline+ & . & . & . & + & + & + \\
\hline+ & + & . & . & + & + & + \\
\hline+ & + & + & . & + & + & \\
\hline+ & + & + & + & . & + & + \\
\hline+ & + & + & + & + & . & + \\
\hline
\end{tabular}

Germination

(phase-bright spores after $2 \mathrm{~h}$ )

$(\%)$

Amino acids ( $\mathrm{I} \mathrm{mm}$ ) included in medium:

Phenylalanine

Leucine

Methionine

Phenylalanine, leucine

Phenylalanine, methionine

Leucine, methionine

Leucine, methionine, phenylalanine

$\begin{array}{rrrrrrr}35 & 52 & 75 & 80 & 62 & 78 & 25 \\ 25 & 28 & 53 & 82 & 65 & 54 & 59 \\ 25 & 7 & 6 & 78 & 7 & 39 & 44 \\ 7 & 17 & 47 & 79 & 73 & 60 & 16 \\ 9 & 9 & 5 & 76 & 36 & 37 & 8 \\ 10 & 9 & 16 & 78 & 25 & 39 & 4 \\ 5 & 7 & 8 & 79 & 28 & 51 & 6\end{array}$

tion with the other three components constant. The $\mathrm{pH}$ was adjusted and maintained with tris- $\mathrm{HCl}$ buffer for tests on the effect of $\mathrm{Na}^{+}$. Lactate was required in higher concentration than methionine or nicotinamide and $\mathrm{Na}^{+}$appeared essential (Fig. 2a). Chloride ions were not involved since tris- $\mathrm{HCl}$ buffer or $\mathrm{KCl}$ did not stimulate germination in the absence of $\mathrm{NaCl}$. Parallel experiments using aerobic conditions (Fig. $2 b$ ) confirmed the necessity for $\mathrm{Na}^{+}$and also showed that under these conditions all the components were essential.

Variation of one or more germinants indicated that there may be two germination systems. Under anaerobic conditions germination will take place in either methionine and $\mathrm{Na}^{+}$or lactate, nicotinamide and $\mathrm{Na}^{+}$, though all the compounds are necessary for the most rapid germination (Table 7). Some earlier results (Shoesmith \& Holland, I968) suggested that a 

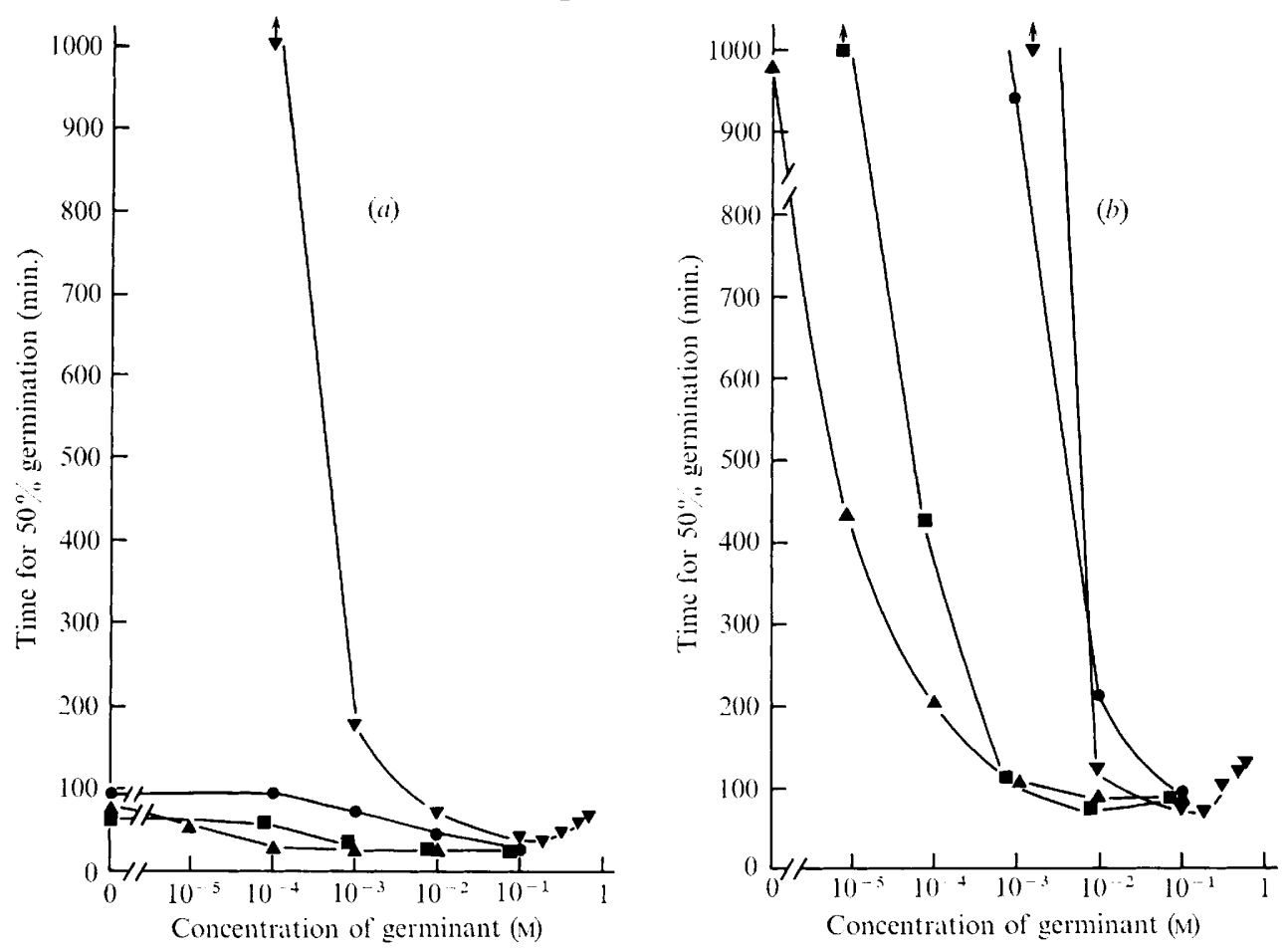

Fig. 2. The rate of germination of Clostridium tetani under anaerobic $(a)$ and aerobic $(b)$ conditions with concentrations of germinants varied one at a time (see text). Times for $50 \%$ germination were derived from graphs of percentage germination against time. The symbols with arrows indicate that the $50 \%$ germination time was > $1000 \mathrm{~min}$. $\mathbf{\square}$, Nicotinamide; $\mathbf{\Delta}$, methionine; lactate; $\mathbf{\nabla}, \mathrm{Na}^{+}$.

Table 7. Anaerobic germination of spores in media of different composition

Compounds for basal medium*

L-Methionine (I mM)

Sodium lactate (100 mM)

Nicotinamide $(82 \mu \mathrm{M})$

Phase-bright spores at $3 \mathrm{~h}(\%)$

Phase-bright spores at $6 \mathrm{~h}(\%)$

\begin{tabular}{|c|c|c|c|c|c|c|}
\hline \multicolumn{7}{|c|}{ Compounds present in basal medium } \\
\hline+ & + & + & . & . & . & + \\
\hline+ & . & + & + & . & + & . \\
\hline+ & + & . & + & + & . & . \\
\hline \multicolumn{7}{|c|}{ Germination } \\
\hline 2 & $2 \mathrm{I}$ & I 2 & I 2 & 98 & 97 & I 8 \\
\hline 0 & 12 & 3 & 3 & 96 & 93 & 7 \\
\hline
\end{tabular}

* Basal medium also contained $280 \mathrm{~mm}-\mathrm{Na}^{+}$and 40 mM-phosphate buffer, $\mathrm{pH} 7 \cdot 5$.

buffer was necessary for germination in methionine, but this was a consequence of $\mathrm{pH}$ changes induced by the decomposition of thioglycollate (Holland \& Shoesmith, 197I).

\section{The effect of reducing agents}

In most of this work thioglycollate was used to maintain anaerobic conditions. With some clostridia this compound is inhibitory (Treadwell, Jann \& Salle, I958; Gibbs, 1964) but not with Clostridium tetani. When germination took place in either heart-infusion broth, or methionine, lactate and nicotinamide, or leucine, phenylalanine, methionine, lactate and 
Table 8. The effect of thioglycollate on the germination of spores in a defined medium

$\begin{array}{cc}\begin{array}{c}\text { Thioglycollate } \\ \text { (mM) }\end{array} & \begin{array}{c}\text { Time for } 50 \% \\ \text { (min) }\end{array} \\ 0 & 41 \\ 0 \cdot 1 & 29 \\ 1 \cdot 0 & 26 \\ \text { IO } & 24 \\ \text { I00 } & 24\end{array}$

Germination took place in the presence of methionine (I mM), lactate (100 mM), nicotinamide $(82 \mu \mathrm{M})$, phosphate buffer (40 $\mathrm{mM}, \mathrm{pH} 7 \cdot 5)$ and $\mathrm{Na}^{+}(280 \mathrm{mM})$ at $37^{\circ}$.

nicotinamide similar results were obtained with either Io mM-thioglycollate or Io mMascorbate as the reducing agent. Cysteine was also effective. Similarly, spore suspensions bubbled with $\mathrm{O}_{2}$-free $\mathrm{N}_{2}$ (British Oxygen Company, Leeds, 12) germinated at the same rate whether thioglycollate was present or not. Different concentrations of thioglycollate up to $100 \mathrm{~mm}$ gave no inhibitory effect (Table 8).

\section{DISCUSSION}

Germination of Clostridium tetani spores is actively stimulated by a combination of I mM-methionine, I00 mM-lactate, $82 \mu \mathrm{m}$-nicotinamide and $280 \mathrm{~mm}-\mathrm{Na}^{+}$, all of which may be readily available in a natural environment such as dead or damaged tissue. Lactate and $\mathrm{Na}^{+}$have already been noted as germinants for Clostridium bifermentans (Gibbs, I964, 1967). These more complex germination requirements may be characteristic for C tetani and therefore useful taxonomically in a similar manner to which Rode (1968) found that Bacillus megaterium could be divided into two types whose germination requirements correlated with other differences.

Other compounds, such as leucine and phenylalanine, have less activity for stimulating germination but are effective with other spores (Hitzmann et al. 1957; Gibbs, I964). Among the other amino acids, alanine, known as a germinant for many other species, was inactive. Bicarbonate, though an active germinant for some clostridia (Holland et al. 1970), was slightly active with Clostridium tetani but only in the presence of leucine and phenylalanine. (The results with these less active germinants have been confirmed and extended in more detailed experiments-Holland, 1969; Holland \& Shoesmith, I97r.)

Under aerobic conditions germination is slow and methionine, lactate, nicotinamide and $\mathrm{Na}^{+}$are all necessary. With these compounds present under anaerobic conditions the time for $50 \%$ germination is shortened by about $60 \%$. Anaerobic conditions also enable germination to take place either in lactate, nicotinamide and $\mathrm{Na}^{+}$or in methionine and $\mathrm{Na}^{+}$, and, though this germination is slower than with all the compounds present, it is faster than the optimal aerobic germination. The germination system is therefore not insensitive to aerobic conditions, showing a response between that of spore viability, which is little affected by oxygen (J. G. Shoesmith, unpublished observations), and cell development, where anaerobic conditions are well known to be necessary for outgrowth and multiplication (Knight \& Fildes, 1930).

A similar dependency of the specificity of germinants on environmental factors (aerobic or anaerobic conditions) has been found with strains of Clostridium sporogenes PA 3679 
(Holland et al. 1969) and Gibbs (1971) found that the presence of bicarbonate made heatshock and phenylalanine no longer necessary for the rapid germination of C. bifermentans.

The authors wish to thank the Medical Research Council for a grant to support this work.

\section{REFERENCES}

BARKeR, A. N., Gould, G. W. \& Wolf, J. (I97I). Spore Research I97I. London: Academic Press.

Bergère, J. L. (1969). La germination de la spore de Clostridium tyrobutyricum. I. Action de différents composés sur la phase initial. Annales de l'Institut Pasteur 117, 179-195.

FuJroKa, R. S. \& FranK, H. A. (I966). Nutritional requirements for germination, outgrowth and vegetative growth of Putrefactive Anaerobe 3679 in a chemically defined medium. Journal of Bacteriology 92, I515-1520.

GiBBs, P. A. (1964). Factors affecting the germination of spores of Clostridium bifermentans. Journal of General Microbiology 37, 41-48.

GisBs, P. A. (1967). The activation of spores of Clostridium bifermentans. Journal of General Microbiology 46, 285-29I.

GibBS, P. A. (1971). Further studies on the germination of spores of Clostridium bifermentans. In Spore Research 197 I. Edited by A. N. Barker, G. W. Gould and J. Wolf. London: Academic Press.

Gould, G. W. \& Hurst, A. (1969). The Bacterial Spore. London: Academic Press.

Hitzman, D. O., Halvorson, H. O. \& UKITA, T. (1957). Requirements for production and germination of spores of an aerobic bacteria. Journal of Bacteriology 74, I-7.

Holland, K. T. (1969). Germination of Spores of Clostridium tetani. Ph.D. Thesis, University of Leeds.

Holland, D. B., BARKER, A. N. \& Wolf, J. (I969). Factors affecting germination of clostridia. In Spores, vol. Iv. Edited by L. L. Campbell. Bethesda, Maryland: American Society for Microbiology.

Holland, D. B., BARKER, A. N. \& Wolf, J. (1970). The effect of carbon dioxide on spore germination in some clostridia. Journal of Applied Bacteriology 33, 274-284.

Holland, K. T. \& Shoesmith, J. G. (1971). Studies on the germination of spores of Clostridium tetani. In Spore Research 1971. Edited by A. N. Barker, G. W. Gould \& J. Wolf. London: Academic Press.

Kaufman, L. \& Humphries, J. G. (1958). Studies of the nutritional requirements of Clostridium tetani. I. A chemically defined medium. Applied Microbiology 6, 3I I-315.

KNIGHT, B. C. J. G. \& Fildes, P. (1930). Oxidation-reduction studies in relation to bacterial growth. 3. The positive limit of oxidation reduction potential required for the germination of Bacillus tetani spores in vitro. Biochemical Journal 24, I496-1502.

OxoId MANUAL (1965). 3rd edn, p. 21 I. London: Oxoid.

RODE, L. J. (1968). Correlation between spore structure and spore properties in Bacillus megaterium. Journal of Bacteriology 95, 1979-1986.

ROWLEY, D. B. \& FeEHERRY, F. (1970). Conditions affecting germination of Clostridium botulinum 62 A spores in a chemically defined medium. Journal of Bacteriology 104, I I 5 I-I 157.

Shoesmith, J. G. (1964). The effect of heat and irradiation on the viability and pathogenicity of Clostridium tetani. Journal of General Microbiology 35, vi.

Shoesmith, J. G. \& Holland, K. T. (I968). The germination requirements of spores of Clostridium tetani. Biochemical Journal ro6, 38 P.

Treadwell, P. E., JanN, G. J. \& Salle, A. J. (1958). Studies on factors affecting the rapid germination of spores of Clostridium botulinum. Journal of Bacteriology 76, 549-556. 